\title{
PERTANGGUNGJAWABAN TERHADAP TINDAK PIDANA PENYELUNDUPAN SEPEDA MOTOR HARLEY OLEH DIREKTUR PT. GARUDA INDONESIA
}

\author{
I Dewa Gede Pramana Adhi, I Nyoman Gede Sugiartha, I Made Minggu Widyantara \\ Fakultas Hukum Universitas Warmadewa, Denpasar-Bali, Indonesia \\ pramanaadhi75gmail.com, nyomansuqiartha14gmail.com, mademinaau2gmail.com
}

\begin{abstract}
Abstrak
Indonesia merupakan Negara berkembang dimana setiap wilayahnya terdapat kekayaan alam tersendiri. Keunggulan ini tidak dapat dimanfaatkan karena banyaknya oknum yang mengirim keluar da erah tanpa izin begitupun sebaliknya barang dari Negara luar yang diseludupkan ke Indonesia hanya untuk menghindari dari pajak yang berlaku. Penelitian ini bertujuan untuk mengkaji pengaturan tindak pidana penyelundupan dalam hukum pidana di Indonesia dan mengungkapkan pertanggungjawaban direktur PT. Garuda Indonesia yang melakukan tindakan penyelundupan sepeda motor mewah. Penelitian ini merupakan tipe penelitian hukum normatif yang dilakukan dengan metode penelitian mengkaji berdasarkan bahan-bahan hukum, sedangkan pendekatan masalah yang digunakan adalah pendekatan peraturan Perundang-undangan dan konseptual. Sumber data yang digunakan yaitu bahan hukum primer dan sekunder. Contoh buruk kembali diperlihatkan oleh salah satu orang yang punya nama besar di Indonesia kasus penyelundupan oleh dirut Garuda Indonesia menjadi gambaran betapa lemahnya hukum di Indonesia dan kejadian ini membuat pelaku dapat sanksi pidana dan administratif. Hasil penelitian menunjukkan bahwa Pengaturan tindak pidana penyelundupan di Indonesia dimuat dalam Undang-undang Nomor 17 Tahun 2006 tentang Kepabeanan. Penanganan atas pelanggaran ketentuan kepabeanan lebi h dititik beratkan pada penyelesaian secara fiseal yakni berupa pembayaran sejumlah uang kepada Negara dalam bentuk denda. Pertanggungjawaban pidana pelaku penyelundupan diatur dalam Undang-ndang Nomor 17 Tahun 2006 direktur utama PT. Garuda Indonesia terancam sanksi pidana dan administratif.
\end{abstract}

Kata kunci: Pidana, Penyeludupan, Pertanggungjawaban

\begin{abstract}
Indonesia is a developing country where each region has its own natural wealth. This advantage cannot be used because there are many people who send out of the region without permission and vice versa, goods from outside countries are smuggled into Indonesia only to avoid the applicable taxes. This study aims to examine the regulation of smuggling in criminal law in Indonesia and reveal the responsibility of the director of PT. Garuda Indonesia, which carried out the act of smuggling luxury motorcycles. This research is a type of normative legal research conducted with research methods based on legal materials, while the problem approach used is a legislative and conceptual approach. Sources of data used are primary and secondary legal materials. Another bad example is shown by one of the people who has a big name in Indonesia, the smuggling case by the president of Garuda Indonesia is an illustration of how weak the law in Indonesia is and this incident has resulted in criminal and administrative sanctions. The results of the study indicate that the regulation of smuggling crimes in Indonesia is contained in Law Number 17 of 2006 concerning Customs. Handling of violations of customs provisions is more focused on the fiscal settlement, namely in the form of payment of a sum of money to the State in the form of a fine. The criminal liability of smugglers is regulated in Law No. 17 of 2006 the president director of PT. Garuda Indonesia is threatened with criminal and administrative sanctions.

Keywords: Crime, Smuggling, Accountability
\end{abstract}

\section{PENDAHULUAN}

Indonesia merupakan Negara yang wilayahnya terdiri dari beberapa pulau mempermudah berbagai kegiatan ilegal dapat dilakukan dengan pengawasan yang tidak begitu ketat, beberapa kali barang ilegal masuk tanpa diketahui sektor keamanan namun sering kali tertangkap basah. Jarak antara pulau yang berbeda-beda membuat semakin banyaknya oknum tertentu dapat melakukan tindakan yang bertentangan dengan hukum positif yang berlaku. Baik dari jalur darat, udara atau laut, yang amatir maupun yang memiliki jabatan kasus penyelundupan tidak ada hentinya di Indonesia. Yang terbaru penyelundupan sepeda motor mewah oleh orang yang memiliki jabatan disalah satu maskapai pen erbangan. Seperti tanpa beban dan malu dengan Ieluasanya orang yang memiliki jabatan berbuat 
seenaknya tanpa memikirkan konsekuensi dari perbuatannya. Berasal dari Iuar negara Indonesia sepeda motor mewah tersebut tanpa pemeriksaan sampai dijakarta dan apesnya pengecekan di dilakukan di Jakarta dan terbukti bahwa bagian-bagian sepeda motor mewah tersebut sebanyak 17 kotak terpisah dan tanpa nama sudah masuk Indonesia (Lopa, 1993).

Banyak orang menyayangkan kejadian tersebut karena sebelum kejadian tersebut baru saja terjadi penyelundupan satwa langka di Indonesia. Kejadian seperti ini sering terjadi namun tidak semua diliput oleh media hanya karena pelakunya kali ini merupakan orang yang memegang jabatan di Garuda Indonesia makanya dipublikasikan dan membuat banyak masyarakat heboh. Disatu sisi kejadian disayangkan masyarakat karena pelaku merupakan orang yang berkecukupan dan dapat dikatakan orang kaya disisi lain banyak masyarakat atau oknum tertentu menjadikan kejadian ini sebagai motivasi atau ajang unjuk gigi karena orang yang memegang kuasa saja bisa kenapa kita yang orang tidak dipandang tidak bisa melakukan perbuatan yang sama yang nantinya tidak akan ada media yang meliput karena bukan orang penting. Pelanggaran hukum positif di Indonesia dibidang penyelundupan sering sekali terjadi dan banyak pertanyaan dari asyarakat apakah hukum di Indonesia hanya sekedar wacana belaka atau pihak yang menyelundupkan barang lebih cerdas ketimbang para penegak hukum. Seperti mati satu tumbuh seribu kejadian penyelundupan ini sudah tidak bisa dihitung jari dan pemerintah sampai memperketat sektor udara, lautan guna menanggulangi tindak pidana penyelundupan yang ada. Pemerintah bekerja sama dengan pihak keamanan dengan membuat peraturan mengenaisanksiyang dapat membuat efek jera bagi pelaku penyelundupan. Selain membuat peraturan mengenai efek jera bagi pelaku pemerintah juga harus memikirkan tindakan pencegahan yang dapat menggagalkan tindakan oknum yang akan menyelundupkan barang ilegal. Penyelundupan merupakan tindakan yang dilarang keras oleh pemerintah dan sudah ada peraturan perundangundangan yang mengatur sanksi bagi siapa saja yang sengaja melakukan penyelundupan baik keluar negara maupun ke dalam negara namun banyak oknum yang tidak memperdulikan karena melihat dari sisi pendapatan atau hasil yang diperoleh setelah berhasil menyeundupkan barang tersebut membuat semakin maraknya kasus penyelundupan ditambah saat ini susahnya mencari pekerjaan membuat banyak oknum berpikir dengan jalan pintas untuk mendapatkan hasil dengan waktu yang singkat tanpa harus mematuhi hukum positif yang berlaku. Penegak hukum dalam menangani kasus penyelundupan Iebih ditin gkatkan dan dilakukan tinda kan dini guna memotong jalur penyelundupan sebelum kejadian disatu sisi demi mengurangi hutang negara dan membuat baik nama penegak hukum yang sudah dianggap masyarakat tidak mampu mengantisipasi dan mengakhiri kaus penyelundupan yang terjadi (Alam, 2010)

Sektor yang menjadi target penyelundupan barang impor adalah bandara, sangat sering pelaku mengelabui dengan menyi sipkan barang impor di sela-sela barang penumpang lainnya yang membuat sulit dideteksi tentu yang dilakukan tidak hanya itu bias anya pel aku sudah menjal in kerja sam a dengan orang dal am ba hkan pelakunya merupakan pekerja di bandara tersebut untuk memastikan barang am an sampai keluar bandara. Kasus yang baru-baru ini terjadi ialah penyelundupan motor harley o'au/c/soe yang dilakukan oleh direktur PT. Garuda Indonesia yang dibawa dari Prancis. Dapat dipa stikan Direktur PT. Garuda Indonesia melanggar hukum positif yang ada di Indonesia dan pelanggaran karena telah menyalahgunakan wewenang yang dipegangnya. Kejadian yang seperti ini membuat pihak maskapai dan pihak bandara menambah ekstra pengawasannya agar kejadian serupa tidak terulang kembali.

Banyak masyarakat mempertanyakan kenapa sampai melakukan hal seperti itu jawabannya karena ingin mendapat keuntungan yang besar dari hasil penjualan sepeda motor tersebut atau akan lebih hemat biaya jika kemudian sepeda motor itu dijadikan kendaraan pribadi. Dalam surat Keterangan Menteri Perindustrian dan Perdagangan Nomor. 229/MPP/Kep/7/1997, pasal 3 Ketentuan umum dibidang impor memang disebutkan bahwa barang yang impor harus dalam keadaan baru kecuali kapal niaga dan kapal ikan . Dalam keputusan tersebut juga disebutkan bahwa, impor hanya boleh dilakukan oleh perusahaan yang telah memiliki angka pengenal importir (API) atau APITerbatas. Motor Harley Davidson tersebut bebas dari biaya bea dan cukai sehingga dikatakan impor ilegal. Hal ini tentu menimbulkan perekonomian yang tidak sehat dan mengakibatkan kerugian Negara. Dengan demikian jelas bahwa masuknya barang tersebut ke Indonesia tidak melalui prosedur sebagaimana disebutkan dalam kebijaksanaan umum dibidang impor sehingga hal tersebut merupakan pelanggaran hukum dibidang ekonomi yaitu pelanggaran yang lebih dikenal dengan sebutan 
penyelundupan (H \& Laseurain, 1995)

\section{METODE PENELITIAN}

Penelitian ini dilakukan dengan mencari data melalui buku ilmu hukum dan menghubungkan dengan permasalahan yang diangkat kemudian mengkaitkan dengan perundang-undangan yang berlaku saat ini (Waluyo, 2002). Dari segi hukum penelitian ini terma suk penelitian normatif. Peneliti mengkaitkan dengan peraturan yang berlaku dan tidak menyimpang dari undang-undang dasar. Pendekatan penelitian dengan cara mengkaji, mencari dan memilah data dari berbagai buku hukum dan berpatokan pada Undang-undang sebagai dasar kajian malasalah yang sedang diteliti. Penelitian ini bertujuan mencari informasi yang akurat dengan mempel ajari gejala masyarakat untuk mendapatkan data yang sebenar-benarnya (Ahmad, 2008).

\section{HASIL DAN PEMBAHASAN}

\section{Pengaturan Tindak Pidana Penyelundupan dalam Hukum Pidana di Indonesia}

Penyelundupan adalah suatu istilah yang dapat kita temukan dalam kehidupan sehari-hari, yang masyarakat umumnya mengartikan sebagai suatu perbuatan pidana yang melanggar suatu peraturan mengenai pema sukan atau pengeluaran barang dari luar Negeri (Pramon, 2014). Penyelundupan atau yang dalam bahasa Inggrisnya smuggling adalah: mengimpor, mengekspor, mengantar pulaukan barang yang berlaku atau tidak memenuhi formalitas pabean yang ditetapkan oleh Undang-undang. Hakikat dari pada penyelundupan adalah menghindari bea masuk/bea keluar supaya mendapatkan keuntungan yang lebih besar, menghindari larangan pemerintah untuk memasukkan barang-barang tertentu yang dilarang oleh pemerintah untuk dimasukkan ke Indonesia.

Pada penyelundupan impor, perbuatan ini dilakukan karena adanya perbedaan yang cukup besar antara harga barang di luar Negeri dengan harga didalam negeri sehingga mengakibatkan orang berusaha untuk menyelundupkan barang tersebut dari luar Negeri kedalam Negeri. Disamping itu ada kemungkinan bahwa barang tersebut diselundupkan masuk ke Indonesia karena barang tersebut di luar Negeri sudah tidak dipakai lagi sehingga harganya sangat murah atau ba hkan tidak dapat diperjual belikan lagi karena dianggap limbah. Jadi orang yang memasukkan barang tersebut akan mengharapkan keuntungan yang sangat besar karena hanya membeli dari pen gumpul dengan harga murah ditambah dengan biaya angkut, sementara barang -barang bekas tersebut dilarang untuk dim asukkan ke Indonesia. Dengan demikian akan diperoleh suatu keuntungan yang sangat besar apabila barang tersebut dapat dimasukkan ke dalam Negeri dan dijual dengan harga yang tinggi (Hartono, 1991)

Pelanggaran hukum positif oleh oknum-oknum tertentu yang dengan keperluan pribadi men cari keunlungan tersendiri dengan memperjualbelikan barang yang dilanggar diperju albelikan atau barang yang dikenakan pajak oleh negara keluar negara dan begitu sebaliknya (Hidayati, 2012). Dalam ketentuan mengenai barang yang dilarang dapat diken akan sanksi berat bagi yang dengan sengaja menyelundupkan barang demi terhindar dari biaya administrasi atau pajak yang berlaku di Indonesia. Penyelundupan sendiri terdiri dari dua jenis yaitu secara impor dan secara ekspor dimana keduanya memiliki kesamaan arti namun dari segi pengirimannya yang berbeda dan dapat dij abarkan sebagai beri kut:

1. Penyelundupan impor merupakan jenis penyelundupan barang yang $\mathrm{m}$ asuk ke dalam negeri, dengan pesaran dari oknum tertentu menggunakan jalur Iaut, darat, atau udara tanpa mengikuti prosedur pengiriman barang yang ada dan informasi yang tertera berbeda dengan barang yang dikirimkan

2. Penyelundupan Ekspor sendiri kebalikan daripada penyelundupan impor dimana pengirim an barang melalui jalur laut, darat dan udara melalui Indonesia keluar negara tanpa mengikuti ketentuan yang berlaku

Selain penyelundupan di atas terdapat beberapa jenis penyelundupan lainnya yaitu secara legal dan Ilegal dibedakan menja didua jenis karena ada beberapa jenis barang yang diijinkan pengirim annya keluar Indonesia namun dengan kelengkapan dokumen dan surat dari pemerintah. Penyelundupan legal merupakan pengiriman barang dari dalam negeri menuju luar negeri dengan urusan kenegaraan dan barang tersebut telah diketahui oleh dua negara atau lebih yang melakukan transaksi dengan mengikuti prosedur semisal dokumen pengiriman dan surat jalan yang berlaku sampai barang tersebut sampai di negara yang dituju. Penyelundupan Ilegal sendiri penyelundupan 
yang isi dan dokumen pelengkapnya tidak sesuai bisa dikatakan barang tersebut disamarkan atau diselipkan ke dalam barang Iain Ialu dikirimkan guna terhindar dari jeratan hukum yang berlaku mengenai penyelundupan. Akibat yang diberikan jika barang ilegal ini diketahui ba gi negara dapat dikenakan denda sesuai dengan negara tujuan pengirim an barang dan bagi pelaku dikenakan sanksi pidana $\mathrm{m}$ aksimal seumur hidup dan sanksi a dministratif yang nantinya akan dipergunakan untuk kebutuhan atau pembangunan infrastruktur negara sesua i dengan ketentuan Undang-undang yang berlaku. Di tingkat pemerintahan lebih terkenal dengan penyelundupan fisik dan penyelundupan a dministratif dengan penjelasan sebagai berikut:

Penyelundupan Fisik

Fisik disini diartikan barang tersebut berbeda dengan isi daripada barang yang dikirimkan dan mencangkup ekspor impor secara sengaja dengan tujuan demi mendapatkan keuntungan tersendiri dan terbukti melakukan tindakan yang berujung merugikan negara. Sanksi pidana diberikan kepada pelaku sebagai efek jera agar kedepan tidak melakukan hal serupa. Penyelundupan yang bersifat rapi. Rapi disini segal anya telah dipersiapkan secara matang mulai dari izin dan dokumen pendukung yang membenarkan isi daripada barang tersebut namun pada kenyataannya tidak. Kepalsuan yang dibuat oknum cerdik ini semat-mata melancarkan penyelundupan ke negara lain atau sebaliknya dengan membungkus barang ke dalam barang lainnya agar tidak dicurigai sebagai barang yang dilarang diperjualbelikan.

\section{Pertanggungjawaban Direktur PT. Garuda Indonesia yang melakukan tindakan penyelundupan sepeda motor mewah}

Pertanggungjawaban pidana sendiri merupakan hasil yang diterima dan suka tida k suka harus dijalani atas akibat karena telah melakukan perbuatan yang melanggar ketentuan hukum yang berlaku di Indonesia. Sanksi diberikan kepada siapa saja dan tida k pandang usia dan golongan selama seseorang melanggar ketentuan pasti mendapat sanksi. Dengan memperhati kan etika, norma dan motif dari pada pelaku pemerintah secara konsisten memberikan hukuman bagi yang melanggar ketentuan. Sudah menjadi kewajiban seseorang untuk mempertanggungjawabkan apa yang telah diperbuat karena sebelum melakukan tindak kejahatan seseorang dapat terlebih dahulu memikirkan sebab akibat dari perbuatan yang akan dikerjakannya. Selain memikirkan sebab akibat pikirkan juga keadaan lingkungan dan keadaan keluarga agar tidak terjadi hal yang membuat nama baik keluarga menjadi tercemar. Penjatuhan hukuman bagi tersangka penyelundupan barang ilegal harus mengikuti unsur yang berlaku dan tetap memandang hak asasi manusia yang ada pada diri tersangka. Perbuatan melanggar ketentuan Perundang-undangan harus diadili guna memberi efek jera bagi oknum Iain yang akan melakukan perbuatan yang sama. Dalam proses pemberian hukuman aturan tentang aparat negara juga diberla kukan dan dilarang bertindak diluar hukum positif yang berlaku. Tindakan pra peradilan sepenuhnya diberikan kepada pihak kepolisian untuk mengetahui dan mencari motif pela ku dan menyaring informasi jika pelaku memiliki jaringan penyelundupan lainnya agar dapat dilakukan pencegahan sedini mungkin sebelum menimbul kan perbuatan yang dapat merugikan negara (Santoso, 2001).

Tindakan ini dilakukan sebelum terjadinya tindak kejahatan dalam tugasnya sebagai kepolisian wajib melaksanakan tindakan ini demi mencegah timbulnya korban maupun kerugian yang dialami masyarakat banyak maupun negara. Norma-norma yang ada dalam diri seseorang diuji disini dimana dalam tindakan prevetif seorang petugas kepolisian harus pandai memprediksi kemungkinan yang akan terjadi pada sebuah kasus tindak kejahatan. Dalam kasus penyelundupan pihak kepolisian bekerja sama dengan masyarakat atau intel (polisi berpakaian preman) untuk menelusuri penyelundupan kapan, dimana dan bagaimana akan terjadi penyelundupan. Dalam kasus penyelundupan sepeda motor mewah ini piha kkepolisian seharusnya bekerja sama dengan polisi tempat akan terjadinya penyelundupan dan menahan pelaku sebelumnya.

Dalam tinda kan preventif dapat dikatakan sebagai tindakan mengantisipasi dimana objek yang akan diselundupkan sudah diamankan terlebih dahulu diamankan oleh kepolisian. Fokus tindakan preventif disini untuk menemukan pihak atau oknum yang berencana melakukan penyelundupan guna menyaring pela ku dari tindakan tersebut dan mencegah terjadinya kerugian negara. Tindakan ini berfokus pa da penangkapan dan pemberian hu kuman bagi pelaku tindak pidana, khusus untuk kasus penyelundupan sepeda motor pihak kepolisian menyerahkan pelaku untuk ditindaklanjuti di meja hijau proses ini sering disebut sebagai law enforcement atau pemberian sanksi. 


\section{SIMPULAN DAN SARAN}

\section{Simpulan}

Berdasarkan hasil analisis data, diketahui bahwa Pengaturan tindak pidana penyelundupan di Indonesia terdapat dalam Undang-undang Nomor 17 Tahun 2006 tentang Kepabeanan. Penanganan atas pelanggaran ketentuan kepabeanan lebih dititik beratkan pada penyelesaian secara fiseal yakni berupa pembayaran sejumlah uang kepada Negara dalam bentuk denda. Dalam hal ini merupakan pengaruh era globalisasi yang menuntut kecepatan dan kelancaran arus barang bagi kemajuan perdagangan nasional dan internasional. Pertanggungjawaban pidana terhadap penyelundupan motor harley davidson yang dilakukan oleh direktur PT. Garuda Indonesia yang dibawa dari Prancis menambah banyaknya kasus tindak pidana penyelundupan yang terjadi di Indonesia. Perbuatan Direktur PT. Garuda Indonesia melanggar hukum positif yang ada di Indonesia dan pelanggaran karena telah menyalahgunakan wewenang yang dipegangnya. Sesuai pengaturan Undang-udndang Nomor 17 Tahun 2006 direktur utama PT. Garuda Indonesia terancam sanksi pidana dan administratif.

\section{Saran}

Berdasarkan simpulan penelitian di atas, adapun saran yang diberikan yaitu diharapkan kepada pemerintah untu menindak tgas pelaku kasus tindak pidana penyelundupan harus dilakukan dengan cepat dan tidak berlarut-larut. Sampai saat ini kasus penyelundupan sepeda motor harley davi dson i ni masih dalam proses penyelidikan padahal kejadian terjadi sudah satu tahun. Di harapkan demi menjaga kepercayaan masyarakat terhadap hukum yang berlaku di Indonesia pihak pihak yang berkaitan dengan jalannya proses penyelidikan kasus penyelundupan sepeda motor harley davi dson ini mempercepat proses hingga terdapat putusan yang dapat membuat efek jera bagi siapa saja yang dengan sengaja melanggar peraturan. Bagi pelaku agar memahami bahwa tindakan yang dilakukan dapat merugikan negara dan Iebih peduli dengan keadaan keluarga dan lingkungan karena bera kibat menyebabkan nama baik diri sendiri dan keluarga menjadi tercemar.

\section{DAFTAR PUSTAKA}

Ahmad, B. (2008). Metode Penelitian Hukum. Pustakasetia

Alam, A. S. (2010). Pengantar Kriminologi. Sura Baya. Pustaka Refleksi Books

H, C., \& Laseurain. (1995). Ekoturisme sebagai Suatu Gejala yang Menyebar ke Seluruh Dunia. PACT dan ALAMI.

Hartono, S. (1991). Politik Hukum Menuju Satu Sistem HukumnNasional. Bandung. Alumni

Hidayati, M. N. (2012). Upaya Pemberantasan dan Pencegahan Perdagangan Orang Melalui Hukum Internasional dan Hukum Positif Indonesia. Jurnal Al-Azhar Indonesia Seri Pranata Sosial, 1(3), 163-174.

Lopa, B. (1993). TinJauan Yuridis Pelapor dalam Tindak Pidana. Jakarta. Damai Jaya

Pramon, P. (2014). Analisis Yuridis terhadap Tindak Pidana Penyelundupan Manusia Berdasarkan Undang-Undang Nomor 6 Tahun 2011 tentang Keimigrasian. Ricidive, 3(2), 124-132

Santoso, T. (2001). Іти Hukum Pidana. Rineka Cipta. Jakarta

Waluyo, B. (2002). Penelitian Hukum Praktek. Sinar Grafika 